\title{
Transferts de techniques et chaînes opératoires
}

\section{Robert Cresswell}

\section{OpenEdition}

Journals

Édition électronique

URL : https://journals.openedition.org/tc/1030

DOI : $10.4000 /$ tc. 1030

ISSN : 1952-420X

\section{Éditeur}

Éditions de l'EHESS

\section{Édition imprimée}

Date de publication : 1 septembre 1983

ISSN : 0248-6016

\section{Référence électronique}

Robert Cresswell, «Transferts de techniques et chaînes opératoires », Techniques \& Culture [En ligne],

2 | 1983, mis en ligne le 26 janvier 2006, consulté le 29 septembre 2022. URL : http://

journals.openedition.org/tc/1030 ; DOI : https://doi.org/10.4000/tc.1030

Ce document a été généré automatiquement le 29 septembre 2022.

Tous droits réservés 


\section{Transferts de techniques et chaînes opératoires}

Robert Cresswell 